Review

\title{
Bacteriocin as Weapons in the Marine Animal-Associated Bacteria Warfare: Inventory and Potential Applications as an Aquaculture Probiotic
}

\author{
Florie Desriac ${ }^{1}$, Diane Defer ${ }^{2}$, Nathalie Bourgougnon ${ }^{2}$, Benjamin Brillet ${ }^{1}$, \\ Patrick Le Chevalier ${ }^{1}$ and Yannick Fleury ${ }^{1, *}$
}

1 Université Européenne de Bretagne, Université de Brest, Institut Universitaire de Technologie, Laboratoire, Universitaire de Biodiversité et d'Ecologie Microbienne EA3882, 6 Rue de 1’Université, 29334 Quimper Cedex, France; E-Mails: floriedesriac@hotmail.fr (F.D.); benjamin.brillet@univ-brest.fr (B.B.); patrick.lechevalier@univ-brest.fr (P.L.C.)

2 Université Européenne de Bretagne, Université de Bretagne Sud, Centre de Recherche Saint Maudé, Laboratoire de Biotechnologie et Chimie Marines EA3884, 56321 Lorient Cedex, France; E-Mails: diane.defer@univ-ubs.fr (D.D.); nathalie.bourgougnon@univ-ubs.fr (N.B.)

* Author to whom correspondence should be addressed; E-Mail: yannick.fleury@univ-brest.fr; Tel.: +33-298-641-930; Fax: +33-298-641-969.

Received: 6 February 2010; in revised form: 28 March 2010 / Accepted: 1 April 2010 / Published: 4 April 2010

\begin{abstract}
As the association of marine animals with bacteria has become more commonly recognized, researchers have increasingly questioned whether these animals actually produce many of the bioactive compounds originally isolated from them. Bacteriocins, ribosomally synthesized antibiotic peptides, constitute one of the most potent weapons to fight against pathogen infections. Indeed, bacteriocinogenic bacteria may prevent pathogen dissemination by occupying the same ecological niche. Bacteriocinogenic strains associated with marine animals are a relevant source for isolation of probiotics. This review draws up an inventory of the marine bacteriocinogenic strains isolated from animalassociated microbial communities, known to date. Bacteriocin-like inhibitory substances (BLIS) and fully-characterized bacteriocins are described. Finally, their applications as probiotics in aquaculture are discussed.
\end{abstract}

Keywords: aquaculture; BLIS; bacteriocin; probiotic 


\begin{abstract}
Abbreviations: APD2: Antimicrobial peptide database 2; BLIS: Bacteriocin-like inhibitory substance; FDA: Food and Drug Administration; GRAS: Generally recognize as safe; LAB: Lactic acid bacteria
\end{abstract}

\title{
1. Introduction
}

According to a FAO report, the average consumption of aquaculture products relative to total per capita fish for human consumption rose from 14\% in 1986 to $47 \%$ in 2006 and it can be expected to reach $50 \%$ in the next few years. However, the development of aquaculture farming will have to be backed up with appropriately relevant management practices, in particular by decreasing its environmental impact and limiting the associated infectious epizooties. Indeed, as in all animal industries, development and intensification generate higher population densities which exacerbate disease processes, leading to stock mortality [1]. Major economic losses in cultured fish worldwide result from a relatively small number of opportunistic pathogens bacteria [2]. Vibrio is one of the most important pathogenic recognized in larval cultures, provoking a high mortality [3,4]. Furthermore, fear of aquaculture farming increases with climate change. Indeed, a recent report has shown that numerous bacteria display greater virulence at higher temperatures due to reduced resistance and increased virulence and transmission [5]. At the same time, use of prophylactic antibiotics is detrimental to aquatic and terrestrial environments, animal and human health [6,7]. That's why authorities such as the European Authority have chosen to limit antibiotic use as a curative situation. In this context, scientific communities have proposed friendly alternatives such as vaccines [1], antibiotic substitutes [8] or use of probiotic [9]. Bacteriocinogenic bacterial strains appear to be an excellent candidate for a friendly alternative since bacteriocin would be used as an antibiotic substitute [10], whereas bacteria would be a potential probiotic [11].

Bacteriocins are ribosomally synthesized proteinaceous compounds, lethal to bacteria closely related to the producing bacteria $[10,12]$, the latter being protected by an immunity phenomenon. The role of bacteriocins in microbial communities hasn't been well-established yet. Bacteriocins may serve as anti-competitor compounds enabling an invasion of a strain or species in an established microbial community [13-15] or act as communication molecules in bacterial consortia like biofilms [11]. Nevertheless, using pure bacteriocins is not practical since it has no economic basis. One way to substitute antibiotics smartly and sustainably will be the selection of bacteriocinogenic and anti-pathogenic strains from animal-associated bacterial microorganisms for use as probiotics.

In this review, the first section deals with a definition of probiotics and their mode of action, while the second part is dedicated to bacteriocin knowledge to date. Then an inventory of marine bacteriocinlike inhibitory substances (BLIS) producing bacteria in the literature is drawn up. The last section is about an efficient strategy to select bacteriocinogenic bacteria.

\section{Probiotics for Aquaculture}

In 1908 Elie Metchnikoff started the discipline of probiotics by reporting for the first time dietary supplements containing potentially beneficial micro-organisms. However, Kollath was the first to 
suggest, in 1953, the term "probiotics" to designate organic or inorganic substances that are essential to a healthy development of life [16]. Two decades later, Parker used the term "probiotic" to describe animal feed supplements that contribute to the gut microbial communities of the host [17]. In 1989, Fuller suggested another definition widely used since: "A live microbial feed supplement which beneficially affects the host animal by improving its intestinal balance" [18]. This revised definition differs from Parker's one by emphasizing the importance of live cells that permit the formal exclusion of antibiotics from the probiotics group. In 1999, Salminen proposed a new definition: "Probiotics are microbial cell preparations or components of microbial cells that have a beneficial effect on the health and well-being of the host" [19]. This implies that non-viable forms of probiotics have also been shown to have health effects and should not restrict the utilization of probiotics in food [20]. The International Scientific Association for Probiotics and Prebiotics recently adopted the definition of the World Health Organization: "Probiotics are live microorganisms which when administrated in adequate amounts confer a health benefit on host" [21].

Nevertheless, none of these definitions fit with aquaculture since aquatic animals have a much closer relationship with their environment than terrestrial ones. In fact, in seawater, pathogens proliferate independently of the host, so opportunistic organisms can reach a high density around aquatic animals [22]. Furthermore, it is admitted that bacteria present in aquatic environments influence the composition of the gut microbiota, with surrounding bacteria being continuously ingested $[23,24]$. The intensive interaction between the environment and the farmed aquatic animals implies that the definition of probiotics has to be adapted for aquaculture. Based on this statement, a new definition for probiotics has been proposed: "A live microbial adjunct which has a beneficial effect on host by modifying the host-associated or ambient microbial community, by ensuring improved use of the feed or enhancing its nutritional value, by enhancing the host response towards disease, or by improving the quality of its ambient environment" [25].

This confers to aquaculture probiotics a large possibility to affect the host health positively [26] by competitive exclusion [27], by enzymatic contribution to digestion [11,28,29] and by enhancement of the immune response [30,31] or by the production of inhibitory substances [9]. Inhibitory substance production is probably one of the most studied modes of probiotic action.

\section{Bacteriocins}

\subsection{Bacteriocin story}

To go back to the first bacteriocin descriptions amounts to studying the first works concerning bacterial antagonism. Such bacterial antagonism was described by the pioneers of microbiology during the last decades of the $19^{\text {th }}$ century. At that time, the molecular basis of bacterial inhibition was abstruse, so it was difficult to distinguish antagonism due to bacteriocins from that provoked by other compounds such as antibiotics, organic acids or hydrogen peroxide, except on the basis of their spectrum of activity, usually narrower than that of the other ones. Although Cornil and Babès suggested a very narrow antagonism within the genus Staphyloccoccus ("le staphylocoque empêche surtout le staphylocoque") in their 1885 treatise of bacteriology [32], the scientific community 
acknowledges the Gratia et al. findings [33] in 1925 as the first documented bacteriocin activity. Indeed, it was named colicin V by the same team in 1949 [34] and later microcin V [35].

The term bacteriocin did not appear until the fifties [34]. This bacteriocin definition is based on the properties of the colicins, that is to say, a lethal biosynthesis, a very narrow spectrum of activity limited to the same species as the producer bacteria and a receptor-mediated mechanism of action [36]. In those days, during the fifties and sixties, the bacteriocin world was mainly made up of bacteriocins from Gram negative bacteria [37,38]. Three genera of Gram positive bacteria were studied for bacteriocin production: Bacillus sp., Listeria sp. and Staphylococcus sp., but it should be noted that during the first half of the 20th century, two lantibiotics, one of the most famous bacteriocins to date, were described. Indeed, the first observations of nisin activity could be those of Roger et al. [39], while subtilin was identified in 1944 from Bacillus subtilis [40]. The exotic amino acid sequences of nisin and subtilin were only elucidated in the early seventies [41,42].

The eighties saw an increase in the number of publications on bacteriocin for both colicin type- and non colicin bacteriocins (Figure 1). But the attribution of nisin GRAS-status by FDA in 1988 [43] would unleash interest in the bacteriocins produced by lactic acid bacteria. Indeed, the industrial applications and the medical and veterinary potential of these microorganisms considered as technological ones are enormous [44-48]. These bacteriocins have aroused a keen interest which has resulted in an exponential increase in the number of publications, while scientific publications about colicins, which may represent the most extensively studied bacteriocins to date, seem to be stabilizing (Figure 1).

Figure 1. Bacteriocin related publications per 10 years period referenced in Pubmed. The bibliographical data bank, Pubmed, was questioned per period of 10 year since 1949. The various keywords employed aimed at distinguishing the various categories of bacteriocins. They were required in title and summary. The different keywords used for query were "Colicin" for colicin, "microcin not colicin" for microcins and "bacteriocin and LAB not colicin not microcin" for LAB bacteriocin.

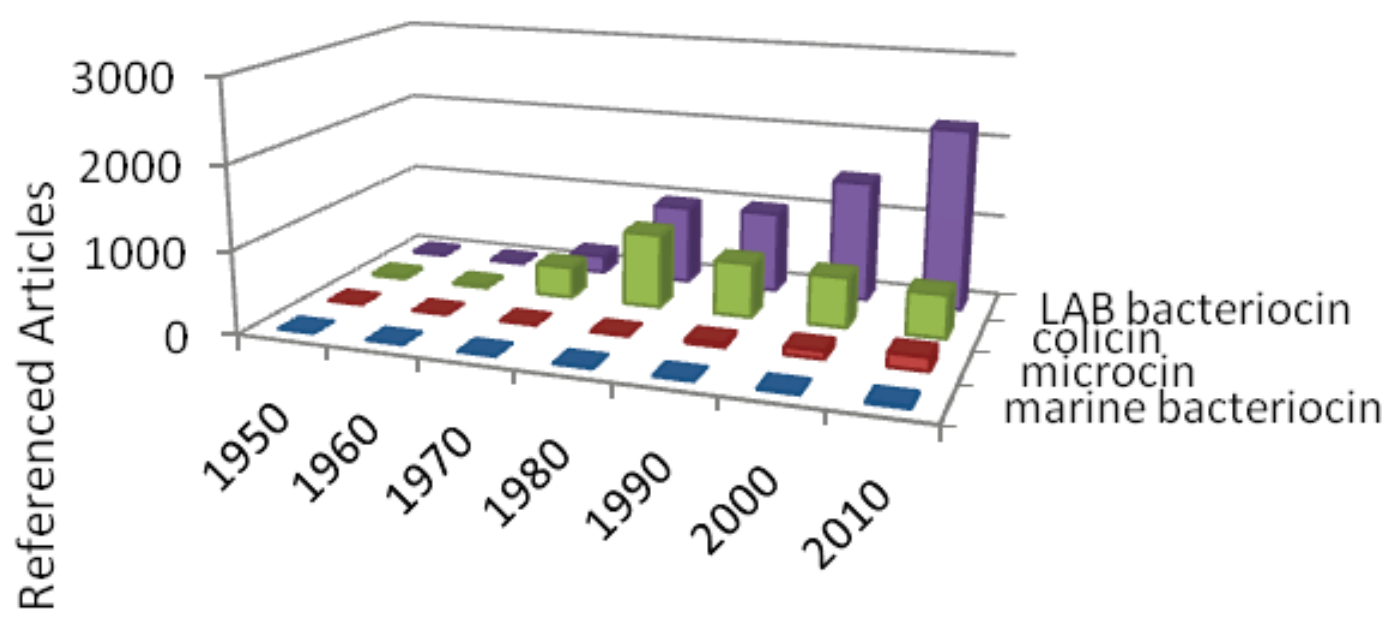

Such interest in LAB bacteriocins has resulted in applications as food preservatives, eg antimicrobial ingredients [45-50]. Over the last 20 years, 706 patents based on LAB bacteriocins activity have been recorded around the World, 421 of which were linked to food preservation, and 124 
to animal probiotics (http://www.freepatentsonline.com). The non LAB bacteriocins are not devoid of application fields. Applications have also been suggested for plant protection $[12,51,52]$, to prevent local infections in humans [53] and recently in aquaculture [11]. Two dedicated freely available bacteriocin online databases have been assembled: BACTIBASE [54] and BAGEL [55]. Moreover, bacteriocins are part of antimicrobial peptides and on this account, are referenced in various antimicrobial peptide databases such as APD2 [56,57] or CyBase [58].

A new category of bacteriocins has emerged over the last two decades: that of the microcins (Figure 1). These may be considered as the "little sisters" of colicins since they exhibit low molecular weight and are produced by enterobacteriae (for reviews see $[35,59,60]$ ). Besides, most microcins exhibit intensive post translational modifications yielding exotic amino acids [61]. In a way, microcins are counterparts of lantibiotics in Gram negative bacteria [61].

Only a few publications are dedicated to bacteriocin production by marine bacteria. Only a few BLIS have been described from marine bacteria and a unique bacteriocin has been fully characterized (see below). In light of marine bacterial biodiversity and the urgent requirement for antibiotic alternatives, we can assume that the marine bacteriocin category will grow exponentially in the near future.

\subsection{Bacteriocin classification}

To date, about two hundred bacteriocins have been characterized (BACTIBASE, BAGEL). Bacteriocin classification is not well-established yet and is still the subject of debate. Although dating back to 1993, the bacteriocin classification defined by Klaenhammer is still the most cited one [62]. An update was proposed by Cotter et al. in 2005 [63] and debated by Heng and Tagg in 2006 [64,65]. Bacteriocins are usually classified combining various criteria. The main ones being the producer bacterial family, their molecular weight and finally their amino acid sequence homologies and/or gene cluster organization. An overview of bacteriocins known to date, proposed in Table 1, shows two main categories: the protein-bacteriocins mainly produced by Gracilicutes, mostly enterobacteriae and the peptide-bacteriocins from Firmicutes, chiefly from LAB. Even so, this statement needs to be qualified since enterobacteriae and $\mathrm{LAB}$ were the main bacteria studied for bacteriocin production. Our feeling is that peptide bacteriocins from Gracilicutes such as microcins are no exceptions.

Colicins are protein-bacteriocins containing about 500-600 amino acid residues [66]. They are organized in three specific domains. Binding to a specific receptor of the target cell, which is the first step of colicin cytotoxic action is governed by the central domain of colicins. The $N$-terminal and $C$-terminal domains are respectively responsible for colicin translocation and antibacterial activity (for a review see [67]). They have been classified in two sub-classes, based on cross resistance [68], translocation system, mechanism of release from the producing cell, and size of encoding plasmids [69]. Group A, translocated by the Tol system and encoded by small plasmids, is composed of colicins A, E1 to E9, K, L, N, S4, U, and Y while group B, translocated by the TonB system and encoded by large plasmids, are made up of colicins B, D, H, Ia, Ib, M, 5, and 10. 
Table 1. Bacteriocin overview.

(A)

\begin{tabular}{|c|c|c|c|c|c|c|}
\hline Protein-Bacteriocins & Class & Sub-Class & Name & MM (kDa) & Mode of action & Ref. \\
\hline \multicolumn{7}{|l|}{ Gracilicutes } \\
\hline \multirow[t]{2}{*}{ Escherichia coli } & Colicins & Groupe A & & 40 to 80 & Nuclease/Pore-forming & {$[69]$} \\
\hline & & Groupe B & & 40 to 80 & Nuclease/Pore-forming & {$[69]$} \\
\hline \multirow[t]{3}{*}{ Pseudomonas aeruginosa } & Pyocins & R-type & Pyocin R2 & $270(\mathrm{AA})$ & Pore-forming & \\
\hline & & S-type & Pyocin S1,S2,AP41 & $75 / 84 / 94$ & Phage-tail like & {$[70]$} \\
\hline & & F-type & Pyocin F & & Phage-tail like & \\
\hline Hafnia alvei & Alveicins & Colicin like & Alveicin A, B & 408/358 (AA) & Pore forming & {$[71]$} \\
\hline Klebsiella pneumonia & Klebicin & Colicin-like & Klebicin C, D & 96 & Nuclease & {$[72,73]$} \\
\hline Serratia plymithicum & Serracin & & Serracin P & 66 & Phage-tail like & {$[74]$} \\
\hline Xanthomonas campestris & Glynericin & & Glynericin A & 50 & Phage tail like & {$[75,76]$} \\
\hline Yersinia enterocolitica & Enterocoliticin & & & 669 & Phage tail like & {$[77]$} \\
\hline Erwinia carotovora & Carotovoricin & & Carotovoricin Er & $68 / 76$ & Phage tail like & {$[78]$} \\
\hline \multicolumn{7}{|l|}{ Firmicutes } \\
\hline Lactobacillus helveticus & Helveticin J & Class III & & 37,5 & to be defined & {$[79]$} \\
\hline Streptococcus milleri & Millericin & Class III & & 30 & Peptidoglycan hydrolysis & {$[80]$} \\
\hline Enterococcus faecalis & Enterolysin & Class III & & 34,5 & Peptidoglycan hydrolysis & {$[81]$} \\
\hline Staphylococcus aureus & Lysostaphin & Class III & & 25 & Peptidoglycan hydrolysis & {$[82,83]$} \\
\hline
\end{tabular}

(B)

\begin{tabular}{|c|c|c|c|c|c|c|c|c|}
\hline Peptide-Bacteriocin & Class & Sub-Class & & Name & MM (kDa) & PTM & Mode of action & Ref. \\
\hline \multicolumn{9}{|l|}{ Gracilicutes } \\
\hline \multirow[t]{3}{*}{ Escherichia coli } & Microcin & Class I & & Microcin B17 & 3.1 & drastic & $\begin{array}{c}\text { intracellular } \\
\text { enzymes }\end{array}$ & \\
\hline & & Class II & IIa & Microcin V & 8.8 & light & pore-forming & {$[35,59,61]$} \\
\hline & & & $\mathrm{IIb}$ & Microcin E492 & 7.9 & drastic & pore forming & \\
\hline \multicolumn{9}{|l|}{ Firmicutes } \\
\hline Lactic acid bacteria & Class I & A-type & A1 & Nisin & 3.5 & drastic & pore-forming & {$[84,85]$} \\
\hline \multirow[t]{6}{*}{ (mainly) } & or Lantibiotic & & $\mathrm{A} 2$ & Lacticin 481 & 3 & drastic & pore forming & [86] \\
\hline & & B-type & & Mersacidin & 2 & & & {$[61]$} \\
\hline & Class II & class IIa & & Pediocin & 4.6 & light & pore forming & {$[48,87]$} \\
\hline & & class IIb & & Plantaricin E/F & $3.5 / 3.7$ & light & pore forming & [88] \\
\hline & & Class IIc & & carnocyclin A & 5.8 & cyclic & pore forming & {$[89,90]$} \\
\hline & & Class IId & & Lactococcin A & 5.8 & none & pore forming & [91] \\
\hline \multicolumn{9}{|l|}{ Cyanobacteria } \\
\hline Prochloron didemni & microcin-like & - & & Patellamides & 0.7 & drastic & & [92] \\
\hline
\end{tabular}

Ref., PTM, AA and ref. respectively mean Review reference, Post-translational modification and amino acids. 
Both groups act on sensitive cells by targeting either the inner membrane by pore formation or an intracellular target using enzymatic activity such as DNAse or RNAse [67]. Bacteriocins of such molecular weight are exceptions in Firmicutes compared with the colicin family. Only two have been described in LAB $[79,80]$. Such protein-bacteriocins produced by LAB have been named class III bacteriocins. The others are specific of Bacillus megaterium [93], Enterococcus faecalis [81] or Staphylococcus aureus [82].

The peptide-bacteriocin group is produced by Gracilicutes and Firmicutes as well. Until 2007, the microcin group was composed of two classes, based on their post-translational modifications [94]. According to their gene cluster organization, this classification has recently evolved [35,59] to give birth to two main classes and two sub-classes. Class I comprises the smallest microcins with molecular masses ranging from $1.1 \mathrm{kDa}$ to $3 \mathrm{kDa}$ (Table 1). They display drastic post-translational modifications leading to exotic structures such as thiazole and oxazole rings in MccB17 (Figure 2). This class acts on sensitive cells by interaction with an intracellular target such as DNA gyrase inhibited by MccB17 [95]. The second microcin class is divided into two sub-classes. The microcin class IIa bridges the gap between colicin and microcin since these peptides are bigger (about $8 \mathrm{kDa}$ ) than a typical microcin and exhibit no modifications with the exception of a single disulfide bond formation. One of them, Microcin V (MccV) was previously called colicin V [35], the first documented bacteriocin [33]. Nevertheless, its gene cluster organization connects them undoubtedly to the microcin family [35]. Unlike previous microcins, class IIb microcins are chromosomally encoded, lacking disulfide bond, exposing a conserved serine-rich C-terminal and carrying for some of them a siderophore-type part (MccE492). MccE492 carries out its antibacterial activity by membrane permeabilization. But it was shown to target inner membrane proteins belonging to the mannose permease family [96].

The other main peptide bacteriocins family is the LAB one. Indeed, of the two hundred or so bacteriocins described to date, almost $90 \%$ are from LAB. With the exception of Helveticin J [79] and Milletricin [80], which are members of class III bacteriocins, they all are of peptidic nature. They have been divided into two main classes: class I and class II, the latter in turn containing three sub-classes (Table 1).

Lantibiotics have been defined as class I. Lantibiotic peptides undergo drastic posttranslational modification leading to unusual amino acid residues such as lanthionine. In a way, they are the counterpart of microcins in Firmicutes. To date, about 50 different lantibiotics have been described in LAB and non LAB bacteria such as Staphylococcus aureus [97]. Overall, lantibiotics are divided on the basis of their topology, that is to say their lanthionine bridge arrangements. Type-A lantibiotics such as nisin (Figure 2) are linear and cationic peptides, while type-B ones are globular [86,98]. The former exerts its antibacterial activity by membrane permeabilization by pore formation in a torroid manner [98] after binding to lipid II, while the latter targets intracellular enzyme function [98]. Another emerging lantibiotic class is the two-component lantibiotics such as haloduracin [99-101].

Class II bacteriocins are lightly modified peptides. These peptides are 20 to 70 amino acid residuelong. Extensive studies have been carried out about their mechanism of action. It has appeared that they use a common global procedure targeting a membrane-embedded domain of an integrated membrane protein [91]. The conformational modifications resulting from membrane proteinbacteriocin interactions lead to membrane perturbations, permeabilization and finally bacterial cell death [102]. It was divided into four sub classes on the basis of their activity. Class IIa was also named 
pediocin-like or anti-Listeria bacteriocins since all of them displayed antibacterial activity against Listeria spp. [62]. These bacteriocins are peptides sharing a highly conserved $N$-terminal part harboring a consensus sequence: -Y-Y-G-N-G-V-X-C-X-X-X-X-C (Figure 2) where C residues are involved in a disulfide bridge [48]. Their more variable C-terminal part has been used for their segregation in four sub-groups $[63,102]$. They act on target cells by a pore-forming mechanism of action $[48,87,102]$. This class constitutes the bacteriocin success story of the last twenty years. Class $\mathrm{IIb}$ is an original antimicrobial peptide class because it is made up of two independent peptides, each being active but both being required for optimal activity [102]. Around twelve such two-component bacteriocins have been described in LAB. Each time, the most active mix was obtained with equivalent concentration of each peptide [88]. LAB bacteriocin group IIc are real cyclic peptides since their $N$ and $C$-termini are covalently connected (for review, the reader is referred to $[63,89]$ ). Their mechanism of action when explored was permeabilization of the inner membrane of target cells leading to cell death. Finally, unmodified and non-pediocin-like peptides and single peptide active bacteriocins form class IId. To date, about 32 different class IId peptides have been described [102].

\subsection{Bacteriocin specificity}

Bacteriocins are unique antimicrobial peptides. Indeed, the producing strain has to protect itself from its own peptides, so bacteriocin-producing bacteria have to develop some sort of immunity strategy. In addition to a structural gene, post-translational gene and export machinery, the gene cluster organization of bacteriocin encodes as well for an immunity protein. The latter ensures bacteriocin protection in various ways, depending on the bacteriocin mechanism of action.

Immunity to pore forming colicins is mediated by a 11 to $18 \mathrm{kDa}$ small membrane protein. A direct and specific interaction within the inner membrane between the immunity protein and the $C$-terminal part of colicin achieves cell protection. Transmembrane helices have been shown to be the main motifs recognized by immunity proteins. Colicins targeting intracellular enzymes such as nuclease are inactivated by direct binding of the immunity protein (about $10 \mathrm{kDa}$ ) to the active domain of colicin leading to a $71-\mathrm{kDa}$ heterodimer.

Microcin immunity still remains opaque, while that towards lantibiotic has been recently reviewed $[103,104]$. Lantibiotic immunity is conferred by lipoprotein intercepting lantibiotic at the cytoplasmic membrane and/or $\mathrm{ABC}$ transporter-type membrane protein complex. Immunity to class II bacteriocins produced by LAB has recently been cleared up [91]. It implies that components of the mannose phosphotransferase system are receptors for both bacteriocin and the imunity protein [105]. To define the role of bacteriocins in producing bacteria is still a challenge. Its production entails advantages in colonizing or defending ecological niches for producing bacteria. 
Figure 2. Covalent structure of some representative peptide-bacteriocins. A: nisin, B: microcin B17, C: pediocin PA-1, D patellamide A.

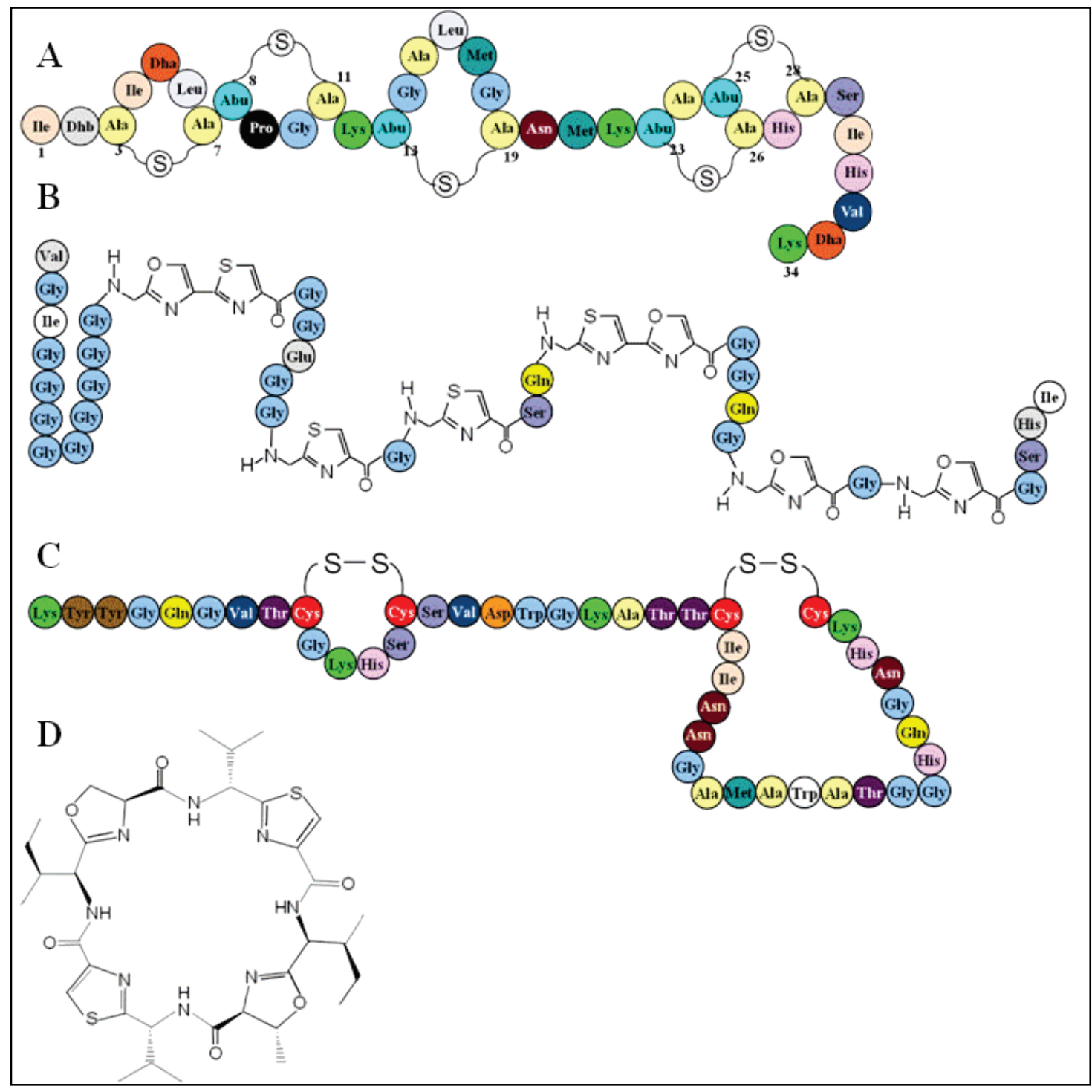

\section{Marine Animal-Associated Microorganisms as Bacteriocin Producers}

Marine animal-associated micro-organisms have been recently studied. Various authors have shown that these bacteria belong to the genera Vibrio, Pseudoalteromonas, Aeromonas, Alteromonas, and to the Cytophaga-Flavobacterium-Bacteroides group [106,107]. Currently, there are relatively few reports in the literature of antibacterial peptide or proteins produced by marine bacteria that have identified step sequence/structure. Wilson et al. [107] have isolated eight marine bacteria which produced antibacterial substances from a variety of different marine invertebrates (oysters, barnacles, sponges, tunicates, sea urchins, seaweeds). The loss of activity, after proteolytic digestion of their extracts, has suggested a proteinceous nature.

An increasing number of compounds with antibacterial activity have been found to be produced by a variety of organisms present in the marine surface environment. Potentially, there are many cases in which products previously attributed to higher organisms may be produced by their associated microorganisms such as patellamide [92]. Finally, numerous studies have evaluated antimicrobial 
marine isolates from sponge, coral, alga and mollusc associated bacteria [106-108]. Nevertheless, only a few studies have focused on marine bacterium isolation from marine animals and the search for their ability to produce bacteriocins (Table 2 ).

\subsection{BLIS from Vibrio $s p$.}

Vibrio species are ubiquitous in the marine environment and are commonly isolated from fish and shellfish specimens [109]. Some species may be pathogenic to marine life, but some do not appear to affect them. Due to their capability to occupy this ecological niche they have been studied for their capacity to produce bacteriocin-like inhibitory substances (BLIS). Zai et al. [110] have isolated and identified fifty strains of the genus Vibrio isolated from the gills and gut region of healthy and infected catfishes (Arianus thalassinus). BLIS was detected and called Vibriocin AVP10 (Table 2).

Fresh and frozen seafood were studied by Carraturo et al. [111]. They have isolated three nonpathogenic (for humans) species of Vibrio ( $V$. mediterranei $1, V$. mediterranei 4 and $V$. fluvialis) displaying antagonistic activity on solid agar medium against pathogenic $V$. parahaemolyticus and $V$. mediterranei. A partial purification of a BLIS produced by $V$. mediterranei 1 was reported. Its proteinaceous nature was revealed by enzymatic degradation by proteinase $\mathrm{K}$. Thanks to size exclusion chromatography, Carraturo et al. [111] have purified an antimicrobial fraction whose molecular mass was determined by SDS-PAGE to be $63-65 \mathrm{kDa}$ corresponding to a mixture of unrelated polypeptides, including the bacteriocin.

Furthermore, $V$. harveyi is a serious pathogen of many vertebrate and invertebrate marine animals [112,113]. McCall and Sizemore [114] have reported for the first time the production of a bacteriocin in a strain of Beneckea harveyi ( $V$. harveyi). The bacteriocin, 'harveyicin SY', with an estimated molecular mass of $24 \mathrm{kDa}$, was lethal to two strains of $V$. harveyi, KN96 and BBP8 (Table 2). Harveyicin SY was susceptible to proteolytic enzymes, and is apparently plasmid associated [114,115].

Prasad et al. [112], whilst screening various $V$. harveyi isolates from their culture collection have recognized a possible BLIS production by a strain of $V$. harveyi (VIB 571). Interestingly, this strain has been demonstrated to be pathogenic to rainbow trout (Oncorhynchus mykiss) and Atlantic salmon (Salmo salar) [113].

Inter-strain and inter-species inhibition mediated by a bacteriocin-like inhibitory substance (BLIS) from $V$. harveyi VIB 571 was demonstrated against four isolates of the same species and $V$. fischeri, $V$. gazogenes and $V$. parahaemolyticus (Table 2). The crude BLIS, which was obtained by ammoniumsulphate precipitation of the cell-free supernatant of a $72 \mathrm{~h}$ broth culture, was inactivated by lipase, proteinase K, pepsin, trypsin, pronase E and SDS. Incubation for $10 \mathrm{~min}$ at more than $60{ }^{\circ} \mathrm{C}$ resulted in loss of activity. On the other hand, antibacterial activity was not affected by $\mathrm{pH}$. Anion-exchange chromatography, gel filtration, SDS-PAGE and two-dimensional gel electrophoresis revealed the presence of a single major peak, comprising a protein with a $\mathrm{pI}$ of $\sim 5.4$ and a molecular mass of $\sim 32 \mathrm{kDa}$ (Table 2). The N-terminal sequencing of the $\sim 32 \mathrm{kDa}$ protein yielded: D-E-Y-I-S-X-N-K-XS-S-A-D-I where ' $\mathrm{X}$ ' may be cystein or modified amino acid residues.

Other vibriocins were isolated by Shehane and Sizemore [116]. Their aim was to identify bacteriocins effective against $V$. vulnificus in seafood. Isolates from estuaries near Wilmington (NC, 
USA) containing plasmids were checked for antimicrobial activity which was not due to lytic bacteriophage or small, non specific molecules. Three bacteriocin producers of $V$. vulnificus were detected and their inhibitory spectra determined (Table 2). Strain IW1 inhibited few strains of $V$. vulnificus; $\mathrm{BC} 1$ inhibited several strains of $V$. vulnificus, $V$. cholerae and $V$. parahaemolyticus and BC2 inhibited all tested Vibrio spp, Plesiomonas shigelloides and E. coli. Loss of inhibitory activity coincided with loss of the bacteriocinogenic plasmid. The molecular weights of the bacteriocins were estimated to be $9.0 \mathrm{kDa}$ for IW1, $7.5 \mathrm{kDa}$ for $\mathrm{BC} 1$ and $1.35 \mathrm{kDa}$ for $\mathrm{BC} 2$ thanks to size exclusion chromatography. IW1 was heat labile, while $\mathrm{BC} 1$ was moderately stable except at extreme temperatures. $\mathrm{BC} 2$ was very stable and maintained its activity when frozen, autoclaved or exposed to extreme $\mathrm{pH}$ values [116]. The authors suggested that these bacteriocins might provide a tool for the removal of $V$. vulnificus from seafood.

Strain Vibrio sp. NM 10 was isolated from spotnape ponyfish (Leiognathus nuchalis) collected in coastal regions of Enoshima Island, Kanagawa, Japan. This strain exhibited high activity against $P$. piscicida K-III, but was also able to inhibit E. coli IAM 1264, V. vulnificus RIMD 2219009 and Enterococcus seriolicida YT-3 [117]. The antibacterial substance produced by Vibrio sp. NM 10 is a proteinaceous heat-labile substance with a molecular mass of less than $5 \mathrm{kDa}$. These facts strongly suggest that the antibacterial substance is either a bacteriocin or a bacteriocin-like substance [117].

\subsection{BLIS from marine Aeromonas $s p$.}

Authors Moro et al. [118] and Messi et al. [119] have shown their interest in evaluating BLIS production in Aeromonas hydrophila. All strains of Aeromonas hydrophila in these two studies demonstrated inhibitory activities against several strains of Staphylococcus aureus (Table 2). Messi et al. [119] have demonstrated further inhibitory effect against Listeria species, Streptococcus agalactiae and Lactobacillus sp. No inhibition was observed against all Gram-negative strains assayed, including related species (Aeromonas sobria ATCC 43979, A. caviae ATCC 13137). Such an inhibitory spectrum is not compatible with the bacteriocin definition.

Table 2. Bacteriocins produced by bacteria isolated from marine environment.

\begin{tabular}{|c|c|c|c|c|c|}
\hline Producing strain & Bacteriocin & Inhibited strain(s) & Isolated from & MM (kDa) & Ref. \\
\hline Listonella anguillarum AVP10 & Vibriocin AVP10 & $\begin{array}{l}\text { Escherichia coli } \\
\text { Listonella anguillarum AVS9 }^{1}\end{array}$ & $\begin{array}{l}\text { Healthy and infected } \\
\text { catfishes } \\
\text { (Arius thalassimus) }\end{array}$ & ? & [110] \\
\hline Vibrio mediterranei & BLIS & $\begin{array}{l}V . \text { parahaemolyticus } \\
V . \text { mediterranei } 5\end{array}$ & $\begin{array}{l}\text { Fresh \& frozen } \\
\text { seafood }\end{array}$ & $63-65^{\mathrm{a}}$ & [111] \\
\hline Vibrio harveyi VIB 571 & BLIS & $\begin{array}{l}\text { Vibrio harveyi }{ }^{1} \\
\text { V. fischeri } \\
\text { V. gazogenes } \\
\text { V. parahaemolyticus }\end{array}$ & - & $\sim 32^{a, b}$ & [112] \\
\hline $\begin{array}{l}\text { Vibrio harveyi (Beneckea } \\
\text { harveyi } \mathrm{SY} \text { ) }\end{array}$ & Harveyicin SY & V. harveyi ${ }^{1}$ & $\begin{array}{l}\text { area of Galveston } \\
\text { Island }\end{array}$ & 24 & {$[114,115]$} \\
\hline
\end{tabular}


Table 2. Cont.

\begin{tabular}{|c|c|c|c|c|c|}
\hline \multirow{3}{*}{ Vibrio vulnificus } & IW1 & $\begin{array}{l}\text { V. vulnificus } \\
\text { V. cholera }\end{array}$ & \multirow{3}{*}{$\begin{array}{l}\text { Water samples from } \\
\text { Wilmington } \\
\text { (NC, USA) }\end{array}$} & 9 & \multirow{3}{*}[116]{} \\
\hline & $\mathrm{BC} 1$ & V. parahaemolyticus & & & \\
\hline & $\mathrm{BC} 2$ & $\begin{array}{l}\text { Vibrio spp. } \\
\text { Plesiomonas shigelloides } \\
\text { E. coli }\end{array}$ & & 1,35 & \\
\hline Vibrio sp. Strain NM 10 & BLIS & $\begin{array}{l}\text { Pasteurella piscicida K-III; } \\
\text { E. coli; } \\
\text { V. vulnificus } \\
\text { Enterococcus seriolicida }\end{array}$ & $\begin{array}{l}\text { Leiognathus nuchalis } \\
\text { intestine }\end{array}$ & $<5^{d}$ & [117] \\
\hline $\begin{array}{l}\text { Bacteriocinogenic strain } \\
\text { marine strain ZM81 (Gram } \\
\text { positif pleomorphic strain) }\end{array}$ & Bacteriocins/ BLIS & Marine bacterial strain ZM19 & $\begin{array}{c}\text { Open sea region of } \\
\text { Karachi coast }\end{array}$ & $>10$ & [120] \\
\hline Aeromonas hydrophila & BLIS & Staphylococcus aureus strains & $\begin{array}{c}\text { Water tank } \\
\text { containing alligators }\end{array}$ & $?$ & $\begin{array}{l}{[118]} \\
{[119]}\end{array}$ \\
\hline $\begin{array}{l}\text { Pseudoalteromonas Species } \\
\text { Strain X153 }\end{array}$ & $\begin{array}{c}\text { Antibiotic protein } \\
\text { P-153 }\end{array}$ & 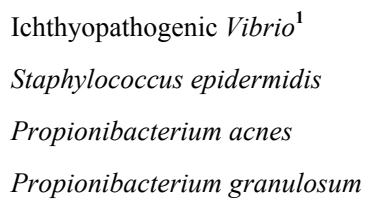 & $\begin{array}{l}\text { Substrates on the } \\
\text { littoral of Brittany }\end{array}$ & $280^{\mathrm{a}, \mathrm{b}}$ & [121] \\
\hline
\end{tabular}

Molecular mass was evaluated using sodium dodecyl sulfate polyacrylamide gel electrophoresis ${ }^{\text {a }}$; size-exclusion chromatography ${ }^{b}$, Mass Spectrometry ${ }^{\mathrm{c}}$ or ultrafiltration ${ }^{\mathrm{d}}{ }^{1}$ : aquacole pathogen. ${ }^{2}$ : bacteriocin isolated from fish intestine. ?: Unknown molecular mass.

\subsection{BLIS from marine Pseudoalteromonas $s p$.}

Longeon et al. [121] investigated bacteria collected from different substrates on the littoral of Brittany and they focused their attention on a Pseudoalteromonas sp. named X-153 that exhibited high antimicrobial activity. Purification of the active protein P-153 from the bacterial cells was achieved. This antibacterial protein was evaluated by size exclusion chromatography to be of $280 \mathrm{kDa}$ size. This antibacterial protein was shown to be active against both gracilicutes (ichthyopathogenic Vibrio) and firmicutes (Staphylococcus epidermidis, Propionibacterium acnes and P. granulosum) (Table 2). Such a broad spectrum of activity is not consistent with the definition of a bacteriocin.

\subsection{Bacteriocin from Firmicutes and LAB associated to marine animals}

It is generally considered that Gram-positive bacteria, including lactic acid bacteria, are numerically dominant members of the normal microbiota in the gastrointestinal tract of endothermic animals at an early stage of their lives [122]. The gastrointestinal microbiota of healthy fish is usually composed of lactic acid bacteria belonging to the genera Streptococcus, Lactobacillus, Carnobacterium, Leuconostoc [122]. Divercins and piscicocins have been fully characterized from Carnobacterium isolated from fish intestine (Table 3). These two bacteriocins belong to class IIa of bacteriocins produced by LAB (see Table 1, for review the reader is referred to [123]). 
In 2004, Pirzada et al. [120] isolated and studied a bacteriocinogenic strain ZM81, a Gram positive pleomorphic rod, which was isolated from the open sea region of Karachi. The proteinaceous nature of the cell-free supernatant of marine strain ZM81 was defined by enzyme degradation with pronase and trypsin. Fractionization of the crude bacteriocin thanks to a molecular weight cut-off membrane showed an enrichment of activity in the fraction containing $>10 \mathrm{kDa}$ bacteriocin-like inhibitory substance. BLIS produced by Marine Bacterium ZM81 is heat labile and exhibits activity within a wide $\mathrm{pH}$ range of 4-12 [120].

Table 3. Bacteriocin produced by Lactic Acid Bacteria isolated from marine animal.

\begin{tabular}{|c|c|c|c|c|c|}
\hline Producing strain & Bacteriocin & Inhibited strain(s) & Isolated from & MM (kDa) & Ref. \\
\hline $\begin{array}{l}\text { Enterococcus faecium } \\
\text { LHICA 28.4, 34.5, 40.4, } 46\end{array}$ & Enterocin P & $\begin{array}{l}\text { Carnobacterium maltaromaticum } \\
\text { Listeria monocytogenes } \\
\text { Staphylococcus aureus }\end{array}$ & Turbot muscle & & [124] \\
\hline Enterococcus faecium ALP7 & bac ALP7 & Listeria monocytogenes & \multirow{2}{*}{$\begin{array}{c}\text { Non-fermented } \\
\text { shellfish including } \\
\text { oysters, mussels and } \\
\text { clams }\end{array}$} & \multirow[b]{2}{*}{$<10$} & \multirow[b]{2}{*}{ [125] } \\
\hline $\begin{array}{l}\text { Pediococcus pentosaceus } \\
\text { ALP57 }\end{array}$ & bac ALP57 & $\begin{array}{l}\text { Bacillus subtilis } \\
\text { Enterococcus faecalis } \\
\text { Lactobacillus brevis gravensis; } \\
\text { Lactobacillus curvatus } \\
\text { Listeria innocua }\end{array}$ & & & \\
\hline $\begin{array}{l}\text { Carnobacterium divergens } \\
\text { V41 }\end{array}$ & Divercin V41 & Listeria monocytogenes & Salmon intestine & 4,509 & [126-129] \\
\hline $\begin{array}{l}\text { Carnobacterium piscicola } \\
\text { V1 }\end{array}$ & $\begin{array}{l}\text { Piscicocin V1a } \\
\text { Piscicocin V1b }\end{array}$ & Listeria monocytogenes & Trout intestine & $\begin{array}{l}4,416 \\
4,526\end{array}$ & {$[128,130]$} \\
\hline
\end{tabular}

\subsection{Bacteriocin from marine cyanobacteria}

While most small peptides found in Cyanobacteria are biosynthesized by nonribosomal peptide synthetases [131], a microcin-like pathway for the biosynthesis of a family of cyclic peptides, the patellamides (Figure 2), has been recently reported in Prochloron didemni, a cyanobacterial symbiont of tropical ascidians [92]. The patellamides are moderately cytotoxic and composed of a pseudosymmetrical, cyclic dimer, with each substructure having the sequence thiazole-nonpolar amino acid-oxazoline-nonpolar amino acid. Despite these unusual features, patellamide biosynthesis is ribosomal [132]. The discovery of patellamides has provided first insight into the biosynthesis of microcin-like peptide distribution and versatility in Cyanobacteria [133].

The patellamide family are cyclic octapeptides (Figure 2) characterized by the presence of thiazole and oxazole moieties. Although nonribosomal biosynthesis was anticipated for the formation of these peptides, heterologous expression of a microcin-like gene cluster discovered in the genome of the cyanobacterium Prochloron didemni unambiguously showed that these peptides are produced by a ribosomal pathway [92,133,134]. An increasing number of other cyclic peptides containing 
heterocyclic amino acids has recently been isolated from planktonic and other animal-associated cyanobacteria, including nostocyclamide [135], tenuecyclamides [136], venturamides [137], dendroamides [138], and microcyclamides [139]. The variety of structures is reflected in an equally large variety of bioactivities, such as antibacterial, cytotoxic, and antimalarial activities [133].

\section{Bacteriocin-Based Strategy to Select a Probiotic for Aquaculture}

In animal or human nutrition, lactic acid bacteria largely dominate the worldwide probiotic market. Actually, they have demonstrated their safety and efficiency over a century. Aquaculture is no exception. Indeed most probiotics used in aquaculture belong to the LAB (for a review the reader is referred to [140,141]). Bacillus genus has also been successfully used in aquaculture [142] makes the list longer by adding marine bacteria belonging to Aeromonas, Pseudomonas, Pseudoalteromonas, Roseobacter and Vibrio and a yeast, Saccharomyces cerevisiae [143]. Moreover, the potential of marine actinobacteria as probiotics in aquaculture has been recently reviewed [144]. All the same, marine bacteria are much less developed as a probiotic source in spite of promising results [143,144]. This may be due to a dissuasive legislation.

The use of probiotics in aquaculture is closely controlled by the administration. In the European Union, probiotics are controlled by regulation CE $n^{\circ} 1831 / 2003$ (OJ L 268 of 18.10.2003) on the use of additives in animal food. Industrialists have to obtain an authorization from the European Food Safety Authority (EFSA), which controls the beneficial effects of probiotics on animal and human health safety and the environment. The safety assessment of microorganisms is in a guideline issued by a relevant scientific committee (SCAN) in 2001. Several specific tests and studies have to be carried out in order to obtain the QSP (Qualified Presumption of Safety) [145]. In the US, probiotics which are used in animal feed are called "direct fed microbials" and are regulated by the Food and Drug Administration. The efficacy and safety of probiotics are examined by the FDA, which can recognize the microorganism as safe (Generally Recognised As Safe). The GRAS-status can be obtained in two ways: some microorganisms have a long history of safety (find them at http://www.cfsan.fda.gov/ dms/opa-micro.html.) or have been recognized by qualified experts as safe under the conditions of intended use [145]. The GRAS concept means that responsibility for safety of the products resides strictly with the producer. To obtain probiotic authorization, the manufacturer has to send a petition to the FDA and the general requirements for this petition are detailed in the US Code of Federal Regulations [146].

We advocate a strategy aiming at preventing establishment of pathogenic bacteria using probiotics. These should be selected from natural indigenous microbial communities associated with marine animals. Bacteriocins are efficient weapons to protect and thus to defend an ecological niche or a nutrient pool. Indeed these peptides combine the most potent activity of related bacteria and a specific spectrum of activity [45]. Thus they constitute a pertinent tool to select a probiotic. So we propose a strategy for probiotic selection based on bacteriocin production ability (Figure 3 ). 
Figure 3. Strategy to select probiotics for aquaculture.

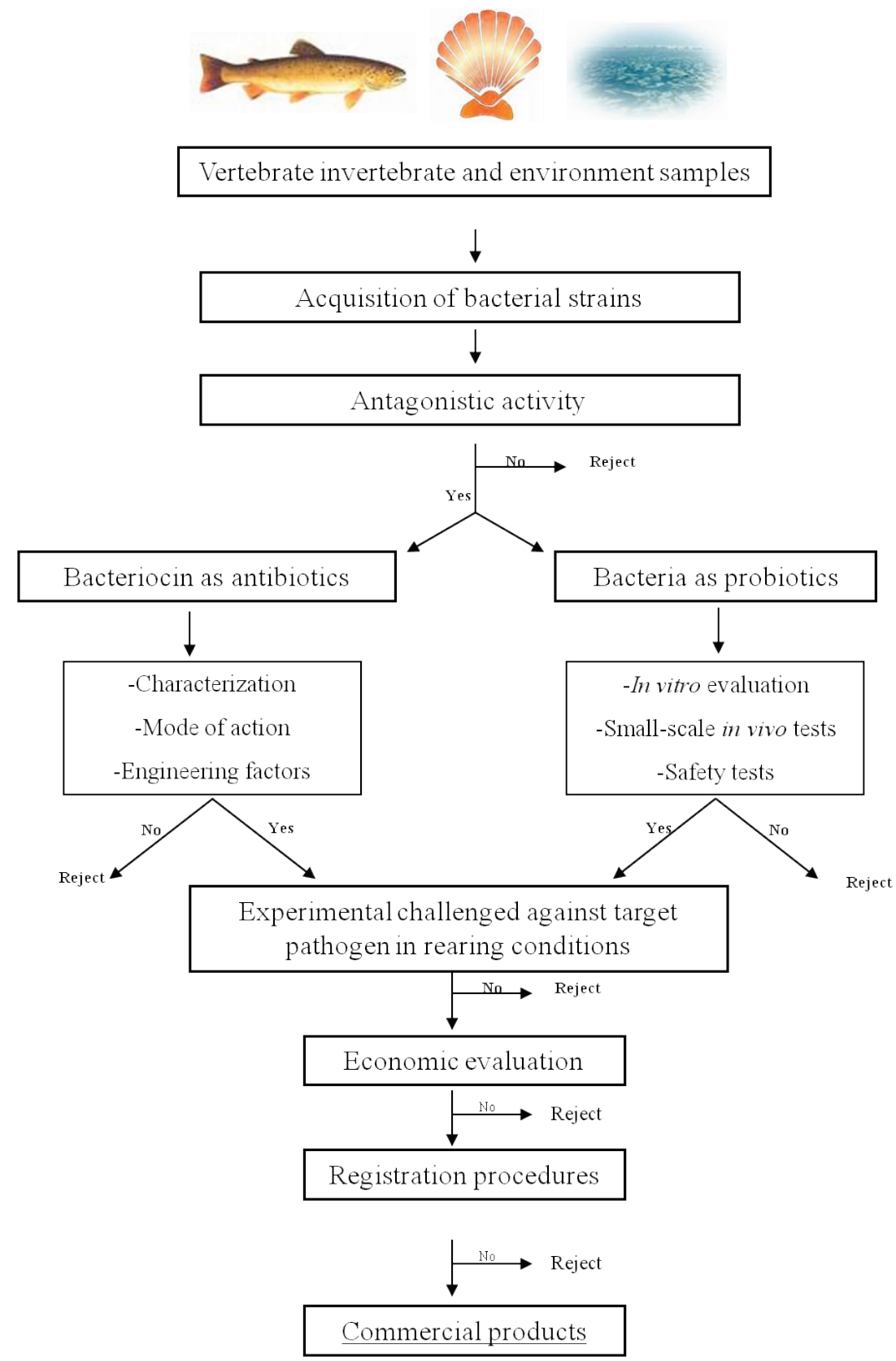

The first step of selection is to screen the animal-associated micro-organisms for antagonistic activities against the selected target cells. This acquisition is one of the major phases of assessment of potential probiotics [147]. Probiotic bacteria for use in aquaculture have to be isolated from indigenous or exogenous microbiota of aquatic vertebrates or invertebrates [27] in order to facilitate establishment and efficiency over temperature and salinity variations of aquaculture farming [144]. This selection is generally carried out by using in vitro antagonist tests [25,144]. Then two ways are possible: the use of the inhibitory compounds as an antibiotic or that of bacteria as probiotics (Figure 3). For the former, research has to be carried out in order to determine the nature of inhibitory compounds, the mode of action, and the genetic aspect of BLIS. However, the administration of purified bacteriocins does not appear to be a cost-effective approach. In face of this need, the second alternative seems to be a more feasible approach. When the putative probiotic is selected, the research has to focus on two parts: the 
evaluation of safety and the beneficial effects under rearing conditions [147]. Safety has to be proved under in-vivo and rearing conditions for the host of course, but also for the environment. Then the commercial procedures can be submitted to the authorities concerned.

It is important to note that probiotics producing antagonistic compounds have to be used in a preventive way [148]. Indeed, a review [149] showed that BS107 (a marine bacteria identified as Roseobacter) cannot be used for treatment when the pathogen is in sufficient concentration to provoke a disease outbreak. In fact, the authors demonstrate that BS107 $\left(10^{6}\right.$ cells $\left./ \mathrm{mL}\right)$ doesn't have any probiotic activity when living cells are co-inoculated with Vibrio pectenicida A496 $\left(10^{4}\right.$ cells $\left./ \mathrm{mL}\right)$.

\section{Conclusions}

Bacteriocins from $\mathrm{LAB}$ have demonstrated their remarkable potential as food conservatives $[13,44-50,63,87,123]$, or as therapeutics for veterinary or medical uses $[13,53]$ or as phytosanitary for plant protection [51]. Extensively studied in LAB and enterobacteriae, little or nothing is known of marine bacteriocins. Only a few have been described, and the fully-characterized ones are exceptions, so knowledge of marine bacteriocins is at the early stages.

Moreover, the increasing scarcity of marine resources ensures a rise in aquaculture in the next decades but also condemns it to set up effective strategies respectful of the environment. In this context, marine bacteriocins that are produced by LAB or autochthonous associated marine bacteria seem to be a relevant alternative to antibiotics. Based on both bacteriocin diversity described to date and the ocean microbial biodiversity, one can predict the discovery of a true peptide arsenal in the coming years. Such an arsenal will find applications in aquaculture. Indeed, the antibiotic approach has to be redrawn. The approach that we recommend rests on different concepts: (i) the most effective strategy to limit epizooties consists in avoiding contact between host and pathogen; (ii) to eradicate pathogenic bacteria is illusory, it's better to occupy its ecological niche (iii) in the case of infections, it is preferable to use active ingredients with a narrow spectrum of antibacterial activity so as to better target the pathogenic ones and limit the risk of resistance development. Bacteriocins are perfect tools to select as probiotics to apply this strategy. One can dream of protective probiotics made up of several BLIS-producing bacteria acting synergistically against pathogens.

\section{Acknowledgements}

This work is performed within the SeaPro Network (www.seapro.fr) in the BIOTECMAR project (contract $n^{\circ} 2008-1 / 032$ ) and is co-financed with the support of the European Union ERDF-Atlantic Area Programme. We acknowledge Hervé Bourdon for English corrections.

\section{References and Notes}

1. Kurath, G. Biotechnology and DNA vaccines for aquatic animals. Rev. Sci. Tech. Off. Int. Epiz. 2008, 27, 175-196.

2. Toranzo, A.E.; Magariños, B.; Romalde, J.L. A review of the main bacterial fish diseases in mariculture systems. Aquaculture 2005, 246, 37-61. 
3. Austin, B.; Zhang, X.H. Vibrio harveyi: a significant pathogen of marine vertebrates and invertebrates. Lett. Appl. Microbiol. 2006, 43, 119-124.

4. Paillard, C.; Le Roux, F.; Borrego, J.J. Bacterial disease in marine bivalves, a review of recent studies: Trends and evolution. Aquat. Living Res. 2004, 17, 477-498.

5. Marcogliese, D. The impact of climate change on the parasites and infectious diseases of aquatic animals. Rev. Sci. Tech. Off. Int. Epiz. 2008, 27, 467-484.

6. Cabello, F.C. Heavy use of prophylactic antibiotics in aquaculture: a growing problem for human and animal health and for the environment. Environ. Microbiol. 2006, 8, 1137-1144.

7. Zhou, Q.; Li, K.; Jun, X.; Bo, L. Role and functions of beneficial microorganisms in sustainable aquaculture. Bioresour. Technol. 2009, 100, 3780-3786.

8. Dorrington, T.; Gomez-Chiarri, M. Antimicrobial Peptides for Use in Oyster Aquaculture: Effect on Pathogens, Commensals, and Eukaryotic Expression Systems. J. Shellfish Res. 2008, 27, 365-374.

9. Kesarcodi-Watson, A.; Kaspar, H.; Lategan, M.J.; Gibson, L. Probiotics in aquaculture: The need, principles and mechanisms of action and screening processes. Aquaculture 2008, 274, $1-14$.

10. Joerger, R.D. Alternatives to antibiotics: bacteriocins, antimicrobial peptides and bacteriophages. Poult. Sci. 2003, 82, 640-647.

11. Gillor, O.; Etzion, A.; Riley, M.A. The dual role of bacteriocins as anti- and probiotics. Appl. Microbiol. Biotechnol. 2008, 81, 591-606.

12. Gillor, O.; Nigro, L.M.; Riley, L.M. Genetically Engineered Bacteriocins and their Potential as the Next Generation of Antimicrobials. Curr. Pharm. Des. 2005, 11, 1067-1075.

13. Lenski, R.E.; Riley, M.A. Chemical warfare from an ecological perspective. Proc. Natl. Acad. Sci. USA 2002, 99, 556-558.

14. Riley, M.A.; Gordon, D.M. The ecological role of bacteriocins in bacterial competition. Trends Microbiol. 1999, 7, 129-133.

15. Riley, M.A.; Wertz, J.E. BACTERIOCINS: Evolution, Ecology, and Application. Annu. Rev. Microbiol. 2002, 56, 117-137.

16. Kollath, W. Nutrition and the tooth system; general review with special reference to vitamins. Dtsch Zahnarztl Z. 1953, 8, Suppl. 7-16.

17. Parker, R.B. Probiotics, the other half of the antibiotic story. Anim. Nutr. Health 1974, 29, 4-8.

18. Fuller, R. Probiotics in man and animals. J. Appl. Microbiol. 1989, 66, 365-378.

19. Salminen, S.; Ouwehand, A.; Benno, Y.; Lee, Y.K. Probiotics: how should they be defined? Trends Food Sci. Technol. 1999, 10, 107-110.

20. Ouwehand, A.C.; Salminen, S.J. The health effects of cultured milk products with viable and non-viable bacteria. Int. Dairy J. 1998, 8, 749-758.

21. Reid, G.; Sanders, M.E.; Gaskins, H.R.; Gibson, G.R.; Mercenier, A.; Rastall, R.; Roberfroid, M.; Rowland, I.; Cherbut, C.; Klaenhammer, T.R. New Scientific Paradigms for Probiotics and Prebiotics. J. Clin. Gastroenterol. 2003, 37, 105-118.

22. Moriarty, D.J.W. Control of luminous Vibrio species in penaeid aquaculture ponds. Aquaculture 1998, 164, 351-358.

23. Cahill, M.M. Bacterial flora of fishes: A review. Microb. Ecol. 1990, 19, 21-41. 
24. Jorquera, M.A.; Silva, F.R.; Riquelme, C.E. Bacteria in the culture of the scallop Argopecten purpuratus (Lamarck, 1819). Aquaculture Int. 2001, 9, 285-303.

25. Verschuere, L.; Rombaut, G.; Sorgeloos, P.; Verstraete, W. Probiotic Bacteria as Biological Control Agents in Aquaculture. Microbiol. Mol. Biol. Rev. 2000, 64, 655-671.

26. Tinh, N.; Dierckens, K.; Sorgeloos, P.; Bossier, P. A review of the functionality of probiotics in the larviculture food chain. Mar. Biotechnol. 2008, 10, 1-12.

27. Balcázar, J.L.; Blas, I.d.; Ruiz-Zarzuela, I.; Cunningham, D.; Vendrell, D.; Múzquiz, J.L. The role of probiotics in aquaculture. Vet. Microbiol. 2006, 114, 173-186.

28. Bomba, A.; Nemcová, R.; Mudronová, D.; Guba, P. The possibilities of potentiating the efficacy of probiotics. Trends Food Sci. Technol. 2002, 13, 121-126.

29. Musa, H.H.; Wu, S.L.; Zhu, C.H.; Seri, H.I.; Zhu, G.Q. The Potential Benefits of Probiotics in Animal Production and Health. J. Anim. Vet. Adv. 2009, 8, 313-321.

30. Isolauri, E.; Sutas, Y.; Kankaanpaa, P.; Arvilommi, H.; Salminen, S. Probiotics: effects on immunity. Am. J. Clin. Nutr. 2001, 73, 444S-450S.

31. Kelly, D.; Conway, S.; Aminov, R. Commensal gut bacteria: mechanisms of immune modulation. Trends Immunol. 2005, 26, 326-333.

32. Cornil, V.; Babes, V. Les bactéries et leur rôle dans l'anatomie et l'histologie pathologiques des maladies infectieuses : ouvrage contenant les méthodes spéciales de la bactériologie; F. Alcan: Paris, France, 1885.

33. Gratia, A. Sur un remarquable exemple d'antagonisme entre deux souches de colibacille. $C . R$. Soc. Biol. 1925, 93, 1040-1041.

34. Fredericq, P.; Joiris, E.; Betz-Barreau, M.; Gratia, A. Recherche des germes producteurs de colicines dans les selles de malades atteints de fièvre paratyphoide. C. R. Soc. Biol. 1949, 143, $556-559$.

35. Duquesne, S.; Destoumieux-Garzon, D.; Peduzzi, J.; Rebuffat, S. Microcins, gene-encoded antibacterial peptides from enterobacteria. Nat. Prod. Rep. 2007, 24, 708-734.

36. Jacob, F.; Lwoff, A.; Siminovitch, A.; Wollman, E. Définition de quelques termes relatifs à la lysogenie. Ann. Inst. Pasteur 1953, 84, 222-224.

37. Bradley, D.E. Ultrastructure of phages and bacteriocins. Bacteriol Rev. 1967, 31, 230-314.

38. Reeves, P. The bacteriocins. Bacteriol Rev. 1965, 29, 24-45.

39. Rogers, L.A. The inhibitory effect of Streptococcus lactis on Lactobacillus bulgaricus. $J$. Bacteriol. 1928, 16, 321-325.

40. Jansen, E.F.; Hirschmann, D.J. Subtilin, an antibacterial product of Bacillus subtilis: culturing conditions and properties. Arch. Biochem. 1944, 4, 297-304.

41. Gross, E.; Kiltz, H.H.; Nebelin, E. Subtilin, VI: the structure of subtilin (author's transl). Hoppe Seylers Z Physiol Chem. 1973, 354, 810-812.

42. Gross, E.; Morell, J.L. Nisin. The assignment of sulfide bridges of beta-methyllanthionine to a novel bicyclic structure of identical ring size. J. Am. Chem. Soc. 1970, 92, 2919-2920.

43. Anonymous. Nisin preparation: Affirmation of GRAS status as a direct human food ingredient. Fed. Regist. 1988, Part 184 53, 11247-11251.

44. Abee, T.; Krockel, L.; Hill, C. Bacteriocins: modes of action and potentials in food preservation and control of food poisoning. Int. J. Food Microbiol. 1995, 28, 169-185. 
45. Deegan, L.H.; Cotter, P.D.; Hill, C.; Ross, P.R. Bacteriocins: Biological tools for biopreservation and shelf-life extension. Int. Dairy J. 2006, 16, 1058-1071.

46. Gálvez, A.; Abriouel, H.; López, R.L.; Omar, N.B. Bacteriocin-based strategies for food biopreservation. Int. J. Food Microbiol. 2007, 120, 51-70.

47. Nes, I.F.; Johnsborg, O. Exploration of antimicrobial potential in LAB by genomics. Curr. Opin. Biotechnol. 2004, 15, 100-104.

48. Papagianni, M.; Anastasiadou, S. Pediocins: The bacteriocins of Pediococci. Sources, production, properties and applications. Microb. Cell Fact. 2009, 8, 3.

49. Juncioni de Arauza, L.; Jozalaa, A.F.; Mazzolab, P.G.; Vessoni Pennaa, T.C. Nisin biotechnological production and application: a review. Trends Food Sci. Technol. 2009, 20, 146-154.

50. Papagianni, M. Ribosomally synthesized peptides with antimicrobial properties: biosynthesis, structure, function and applications. Biotechnol. Adv. 2003, 21, 465-499.

51. Holtsmark, I.; Eijsink, V.G.; Brurberg, M.B. Bacteriocins from plant pathogenic bacteria. FEMS Microbiol. Lett. 2008, 280, 1-7.

52. Vidaver, A.K. Bacteriocins: the lure and the reality. Plant Dis. 1983, 67, 471-474.

53. Tagg, J.R.; Dierksen, K.P. Bacterial replacement therapy: adapting 'germ warfare' to infection prevention. Trends Biotechnol. 2003, 21, 217-223.

54. Hammami, R.; Zouhir, A.; Ben Hamida, J.; Fliss, I. BACTIBASE: a new web-accessible database for bacteriocin characterization. BMC Microbiol. 2007, 7, 89.

55. de Jong, A.; van Hijum, S.A.; Bijlsma, J.J.; Kok, J.; Kuipers, O.P. BAGEL: a web-based bacteriocin genome mining tool. Nucleic Acids Res. 2006, 34, W273-W279.

56. Wang, G.; Li, X.; Wang, Z. APD2: the updated antimicrobial peptide database and its application in peptide design. Nucleic Acids Res. 2009, 37, D933-D937.

57. Wang, Z.; Wang, G. APD: the Antimicrobial Peptide Database. Nucleic Acids Res. 2004, 32, D590-D592.

58. Wang, C.K.; Kaas, Q.; Chiche, L.; Craik, D.J. CyBase: a database of cyclic protein sequences and structures, with applications in protein discovery and engineering. Nucleic Acids Res. 2008, 36, D206-D210.

59. Duquesne, S.; Petit, V.; Peduzzi, J.; Rebuffat, S. Structural and functional diversity of microcins, gene-encoded antibacterial peptides from enterobacteria. J. Mol. Microbiol. Biotechnol. 2007, 13, 200-209.

60. Severinov, K.; Semenova, E.; Kazakov, A.; Kazakov, T.; Gelfand, M.S. Low-molecular-weight post-translationally modified microcins. Mol. Microbiol. 2007, 65, 1380-1394.

61. Jack, R.W.; Jung, G. Lantibiotics and microcins: polypeptides with unusual chemical diversity. Curr. Opin. Chem. Biol. 2000, 4, 310-317.

62. Klaenhammer, T.R. Genetics of bacteriocins produced by lactic acid bacteria. FEMS Microbiol. Rev. 1993, 12, 39-85.

63. Cotter, P.D.; Hill, C.; Ross, R.P. Bacteriocins: developing innate immunity for food. Nat. Rev. Microbiol. 2005, 3, 777-788.

64. Cotter, P.D.; Hill, C.; Ross, P.R. What's in a name? Class distinction for bacteriocins. Nat. Rev. Microbiol. 2006, 4, doi:10.1038/nrmicro1273-c1. 
65. Heng, N.C.K.; Tagg, J.R. What's in a name? Class distinction for bacteriocins. Nat. Rev. Microbiol. 2006, 4, doi:10.1038/nrmicro1273-c1.

66. Riley, M.A. Molecular mechanisms of bacteriocin evolution. Annu. Rev. Genet. 1998, 32, $255-278$.

67. Cascales, E.; Buchanan, S.K.; Duche, D.; Kleanthous, C.; Lloubes, R.; Postle, K.; Riley, M.; Slatin, S.; Cavard, D. Colicin biology. Microbiol. Mol. Biol. Rev. 2007, 71, 158-229.

68. Davies, J.K.; Reeves, P. Genetics of resistance to colicins in Escherichia coli K12: crossresistance among resistance of group A. J. Bacteriol. 1975, 123, 102-117.

69. Riley, M.A.; Wertz, J.E. Bacteriocin diversity: ecological and evolutionary perspectives. Biochimie 2002, 84, 357-364.

70. Duport, C.; Baysse, C.; Michel-Briand, Y. Molecular characterization of pyocin S3, a novel Stype pyocin from Pseudomonas aeruginosa. J. Biol. Chem. 1995, 270, 8920-8927.

71. Wertz, J.E.; Riley, M.A. Chimeric nature of two plasmids of Hafnia alvei encoding the bacteriocins alveicins A and B. J. Bacteriol. 2004, 186, 1598-1605.

72. James, R. Molecular Cloning and Purification of Klebicin B. J. Gen. Microbiol. 1988, 134, 2525-2533.

73. Riley, M.A.; Pinou, T.; Wertz, J.E.; Tan, Y.; Valletta, C.M. Molecular characterization of the klebicin B plasmid of Klebsiella pneumoniae. Plasmid 2001, 45, 209-221.

74. Jabrane, A.; Sabri, A.; Compere, P.; Jacques, P.; Vandenberghe, I.; Van Beeumen, J.; Thonart, P. Characterization of serracin $\mathrm{P}$, a phage-tail-like bacteriocin, and its activity against Erwinia amylovora, the fire blight pathogen. Appl. Environ. Microbiol. 2002, 68, 5704-5710.

75. Heu, S.; Oh, J.; Kang, Y.; Ryu, S.; Cho, S.K.; Cho, Y.; Cho, M. gly gene cloning and expression and purification of glycinecin A, a bacteriocin produced by Xanthomonas campestris pv. glycines 8ra. Appl. Environ. Microbiol. 2001, 67, 4105-4110.

76. Pham, H.T.; Riu, K.Z.; Jang, K.M.; Cho, S.K.; Cho, M. Bactericidal activity of glycinecin A, a bacteriocin derived from Xanthomonas campestris pv. glycines, on phytopathogenic Xanthomonas campestris pv. vesicatoria cells. Appl. Environ. Microbiol. 2004, 70, 4486-4490.

77. Strauch, E.; Kaspar, H.; Schaudinn, C.; Dersch, P.; Madela, K.; Gewinner, C.; Hertwig, S.; Wecke, J.; Appel, B. Characterization of enterocoliticin, a phage tail-like bacteriocin, and its effect on pathogenic Yersinia enterocolitica strains. Appl. Environ. Microbiol. 2001, 67, 5634-5642.

78. Nguyen, H.A.; Kaneko, J.; Kamio, Y. Temperature-dependent production of carotovoricin Er and pectin lyase in phytopathogenic Erwinia carotovora subsp. carotovora Er. Biosci. Biotech. Biochem. 2002, 66, 444-447.

79. Joerger, M.C.; Klaenhammer, T.R. Cloning, expression, and nucleotide sequence of the Lactobacillus helveticus 481 gene encoding the bacteriocin helveticin J. J. Bacteriol. 1990, 172, 6339-6347.

80. Beukes, M.; Bierbaum, G.; Sahl, H.G.; Hastings, J.W. Purification and partial characterization of a murein hydrolase, millericin B, produced by Streptococcus milleri NMSCC 061. Appl. Environ. Microbiol. 2000, 66, 23-28.

81. Nilsen, T.; Nes, I.F.; Holo, H. Enterolysin A, a cell wall-degrading bacteriocin from enterococcus faecalis LMG 2333. Appl. Environ. Microbiol. 2003, 69, 2975-2984. 
82. Kumar, J.K. Lysostaphin: an antistaphylococcal agent. Appl. Environ. Microbiol. 2008, 80, $555-561$.

83. Trayer, H.R.; Buckley, C.E. Molecular properties of Lysostaphin, a bacteriolytic agent specific for staphylococcus aureus. J. Biol. Chem. 1970, 245, 4842-4846.

84. Brotz, H.; Sahl, H.G. New insights into the mechanism of action of lantibiotics--diverse biological effects by binding to the same molecular target. J. Antimicrob. Chemother. 2000, 46, $1-6$.

85. Nagao, J.; Asaduzzaman, S.M.; Aso, Y.; Okuda, K.; Nakayama, J.; Sonomoto, K. Lantibiotics: insight and foresight for new paradigm. J. Biosci. Bioeng. 2006, 102, 139-149.

86. Dufour, A.; Hindré, T.; Haras, D.; Le Pennec, J.-P. The biologyof lantibiotics fromthe lacticin481group is coming of age. FEMS Microbiol. Rev. 2007, 31, 134-167.

87. Drider, D.; Fimland, G.; Hechard, Y.; McMullen, L.M.; Prevost, H. The continuing story of class IIa bacteriocins. Microbiol. Mol. Biol. Rev. 2006, 70, 564-582.

88. Oppegård, C.; Rogne, P.; Emanuelsen, L.; Kristiansen, P.E.; Fimland, G.; Nissen-Meyer, J. The Two-Peptide Class II bacteriocins: structure, production, and mode of action. J. Mol. Microbiol. Biotechnol. 2007, 13, 210-219.

89. Maqueda, M.; Sánchez-Hidalgo, M.; Fernández, M.; Montalbán-López, M.; Valdivia, E.; Martínez-Bueno, M. Genetic features of circular bacteriocins produced by Gram-positive bacteria. FEMS Microbiol. Rev. 2008, 32, 2-22.

90. Martin-Visscher, L.A.; Gong, X.; Duszyk, M.; Vederas, J.C. The three-dimensional structure of carnocyclin A reveals that many circular bacteriocins share a common structural motif. J. Biol. Chem. 2009, 284, 28674-28681.

91. Diep, D.B.; Skaugen, M.; Salehian, Z.; Holo, H.; Nes, I.F. Common mechanisms of target cell recognition and immunity for class II bacteriocins. Proc. Natl. Acad. Sci. USA 2007, 104, 2384-2389.

92. Schmidt, E.W.; Nelson, J.T.; Rasko, D.A.; Sudek, S.; Eisen, J.A.; Haygood, M.G.; Ravel, J. Patellamide $\mathrm{A}$ and $\mathrm{C}$ biosynthesis by a microcin-like pathway in Prochloron didemni, the cyanobacterial symbiont of Lissoclinum patella. Proc. Natl. Acad. Sci. USA 2005, 102, 7315-7320.

93. Kiss, A.; Baliko, G.; Csorba, A.; Chuluunbaatar, T.; Medzihradszky, K.F.; Alfoldi, L. Cloning and characterization of the DNA region responsible for Megacin A-216 production in Bacillus megaterium 216. J. Bacteriol. 2008, 190, 6448-6457.

94. Pons, A.M.; Lanneluc, I.; Cottenceau, G.; Sable, S. New developments in non-post translationally modified microcins. Biochimie 2002, 84, 531-537.

95. Parks, W.M.; Bottrill, A.R.; Pierrat, O.A.; Durrant, M.C.; Maxwell, A. The action of the bacterial toxin, microcin B17, on DNA gyrase. Biochimie 2007, 89, 500-507.

96. Bieler, S.; Silva, F.; Soto, C.; Belin, D. Bactericidal activity of both secreted and nonsecreted microcin E492 requires the mannose permease. J. Bacteriol. 2006, 188, 7049-7061.

97. Bastos, M.C.; Ceotto, H.; Coelho, M.L.; Nascimento, J.S. Staphylococcal antimicrobial peptides: relevant properties and potential biotechnological applications. Curr. Pharm. Biotechnol. 2009, $10,38-61$. 
98. Bierbaum, G.; Sahl, H.G. Lantibiotics: mode of action, biosynthesis and bioengineering. Curr. Pharm. Biotechnol. 2009, 10, 2-18.

99. Breukink, E. A lesson in efficient killing from two-component lantibiotics. Mol. Microbiol. 2006, 61, 271-273.

100. Cooper, L.E.; McClerren, A.L.; Chary, A.; van der Donk, W.A. Structure-activity relationship studies of the two-component lantibiotic haloduracin. Chem. Biol. 2008, 15, 1035-1045.

101. Lawton, E.M.; Ross, R.P.; Hill, C.; Cotter, P.D. Two-peptide lantibiotics: a medical perspective. Mini-Rev. Med. Chem. 2007, 7, 1236-1247.

102. Nissen-Meyer, J.; Rogne, P.; Oppegard, C.; Haugen, H.S.; Kristiansen, P.E. Structure-Function Relationships of the Non-Lanthionine-Containing Peptide (class II) Bacteriocins Produced by Gram-Positive Bacteria. Curr. Pharm. Biotechnol. 2009, 10, 19-37.

103. Draper, L.A.; Ross, R.P.; Hill, C.; Cotter, P.D. Lantibiotic immunity. Curr. Protein Pept. Sci. 2008, 9, 39-49.

104. Lubelski, J.; Rink, R.; Khusainov, R.; Moll, G.N.; Kuipers, O.P. Biosynthesis, immunity, regulation, mode of action and engineering of the model lantibiotic nisin. Cell. Mol. Life Sci. 2008, 65, 455-476.

105. Kjos, M.; Nes, I.F.; Diep, D.B. Class II one-peptide bacteriocins target a phylogenetically defined subgroup of mannose phosphotransferase systems on sensitive cells. Microbiology 2009, 155, 2949-2961.

106. Romanenko, L.A.; Uchino, M.; Kalinovskaya, N.I.; Mikhailov, V.V. Isolation, phylogenetic analysis and screening of marine mollusc-associated bacteria for antimicrobial, hemolytic and surface activities. Microbiol. Res. 2008, 163, 633-644.

107. Wilson, G.S.; Raftos, D.A.; Corrigan, S.L.; Nair, S.V. Diversity and antimicrobial activities of surface-attached marine bacteria from Sydney Harbour, Australia. Microbiol. Res. 2009, in Press.

108. Selvin, J.; Joseph, S.; Asha, K.R.; Manjusha, W.A.; Sangeetha, V.S.; Jayaseema, D.M.; Antony, M.C.; Denslin Vinitha, A.J. Antibacterial potential of antagonistic Streptomyces sp. isolated from marine sponge Dendrilla nigra. FEMS Microbiol. Ecol. 2004, 50, 117-122.

109. Morris, J.J.Â.G. Cholera and Other Types of Vibriosis: A Story of Human Pandemics and Oysters on the Half Shell. Clin. Infect. Dis. 2003, 37, 272-280.

110. Zai, A.S.; Ahmad, S.; Rasool, S.A. Bacteriocin production by indigenous marine catfish associated Vibrio spp. Pak. J. Pharm. Sci. 2009, 22, 162-167.

111. Carraturo, A.; Raieta, K.; Ottaviani, D.; Russo, G.L. Inhibition of Vibrio parahaemolyticus by a bacteriocin-like inhibitory substance (BLIS) produced by Vibrio mediterranei 1. J. Appl. Microbiol. 2006, 101, 234-241.

112. Prasad, S.; Morris, P.C.; Hansen, R.; Meaden, P.G.; Austin, B. A novel bacteriocin-like substance (BLIS) from a pathogenic strain of Vibrio harveyi. Microbiology 2005, 151, 3051-3058.

113. Zhang, X.-H.; Austin, B. Pathogenicity of Vibrio harveyi to salmonids. J. Fish Dis. 2000, 23, 93-102.

114. McCall, J.O.; Sizemore, R.K. Description of a bacteriocinogenic plasmid in Beneckea harveyi. Appl. Environ. Microbiol. 1979, 38, 974-979. 
115. Hoyt, P.R.; Sizemore, R.K. Competitive Dominance by a Bacteriocin-Producing Vibrio harveyi Strain. Appl. Environ. Microbiol. 1982, 44, 653-658.

116. Shehane, S.D.; Sizemore, R.K. Isolation and preliminary characterization of bacteriocins produced by Vibrio vulnificus. J. Appl. Microbiol. 2002, 92, 322-328.

117. Sugita, H.; Matsuo, N.; Hirose, Y.; Iwato, M.; Deguchi, Y. Vibrio sp. strain NM 10, isolated from the intestine of a Japanese coastal fish, has an inhibitory effect against Pasteurella piscicida. Appl. Environ. Microbiol. 1997, 63, 4986-4989.

118. Pedron Moro, E.M.; Niederauer Weiss, R.D.; Salete Friedrich, R.; Paiva Nunes, M. Bacteriocinlike Substance of Aeromonas hydrophila. Mem. Inst. Oswaldo Cruz 1997, 92, 115-116.

119. Messi, P.; Guerrieri, E.; Bondi, M. Bacteriocin-like substance (BLS) production in Aeromonas hydrophila water isolates. FEMS Microbiol. Lett. 2003, 220, 121-125.

120. Pirzada, Z.A.; Ali, S.A.; Khan, B.M.; Rasool, S.A. Production And Physico-Chemical Characterization Of Bacteriocins-Like Inhibitory Substances From Marine Bacterium ZM81. Pak. J. Biol. Sci. 2004, 7, 2026-2030.

121. Longeon, A.; Peduzzi, J.; Barthelemy, M.; Corre, S.; Nicolas, J.-L.; Guyot, M. Purification and Partial Identification of Novel Antimicrobial Protein from Marine Bacterium Pseudoalteromonas Species Strain X153. Mar. Biotechnol. 2004, 6, 633-641.

122. Ringø, E.; Gatesoupe, F.J. Lactic acid bacteria in fish: a review. Aquaculture 1998, 160, 177-203.

123. Rihakova, J.; Belguesmia, Y.; Petit, V.W.; Pilet, M.F.; Prevost, H.; Dousset, X.; Drider, D. Divercin V41 from gene characterization to food applications: 1998-2008, a decade of solved and unsolved questions. Lett. Appl. Microbiol. 2009, 48, 1-7.

124. Hosseini, S.V.; Arlindo, S.; Böhme, K.; Fernández-No, C.; Calo-Mata, P.; Barros-Velázquez, J. Molecular and probiotic characterization of bacteriocin-producing Enterococcus faecium strains isolated from non fermented animal foods. J. Appl. Microbiol. 2009, 107, 1392-1403.

125. Pinto, A.L.; Fernandes, M.; Pinto, C.; Albano, H.; Castilho, F.; Teixeira, P.; Gibbs, P.A. Characterization of anti-Listeria bacteriocins isolated from shellfish: Potential antimicrobials to control non-fermented seafood. Int. J. Food Microbiol. 2009, 129, 50-58.

126. Duffes, F.; Leroi, F.; Boyaval, P.; Dousset, X. Inhibition of Listeria monocytogenes by Carnobacterium spp. strains in a simulated cold smoked fish system stored at $4{ }^{\circ} \mathrm{C}$. Int. J. Food Microbiol. 1999, 47, 33-42.

127. Métivier, A.; Pilet, M.-F.; Dousset, X.; Sorokine, O.; Anglade, P.; Zagorec, M.; Piard, J.-C.; Marion, D.; Cenatiempo, Y.; Fremaux, C. Divercin V41, a new bacteriocin with two disulphide bonds produced by Carnobacterium divergens V41: primary structure and genomic organization. Microbiology 1998, 144, 2837-2844.

128. Pilet, M.-F.; Dousser, X.; Barre, R.; Novel, G.; Dezmazeaud, M.; Piard, J.-C. Evidence for two bacteriocins produced by Carnobacterium piscicola and Carnobacterium divergens isolated from fish and active against Listeria monocytogenes. J. Food Prot. 1995, 58, 256-262.

129. Richard, C.; Drider, D.; Elmorjani, K.; Marion, D.; Prevost, H. Heterologous Expression and Purification of Active Divercin V41, a Class IIa Bacteriocin Encoded by a Synthetic Gene in Escherichia coli. J. Bacteriol. 2004, 186, 4276-4284. 
130. Bhugaloo-Vial, P.; Dousset, X.; Metivier, A.; Sorokine, O.; Anglade, P.; Boyaval, P.; Marion, D. Purification and amino acid sequences of piscicocins V1a and V1b, two class IIa bacteriocins secreted by Carnobacterium piscicola V1 that display significantly different levels of specific inhibitory activity. Appl. Environ. Microbiol. 1996, 62, 4410-4416.

131. Moore, B.S. Biosynthesis of marine natural products: microorganisms (Part A). Nat. Prod. Rep. 2005, 22, 580-593.

132. Sudek, S.; Haygood, M.G.; Youssef, D.T.A.; Schmidt, E.W. Structure of Trichamide, a Cyclic Peptide from the Bloom-Forming Cyanobacterium Trichodesmium erythraeum, Predicted from the Genome Sequence. Appl. Environ. Microbiol. 2006, 72, 4382-4387.

133. Ziemert, N.; Ishida, K.; Quillardet, P.; Bouchier, C.; Hertweck, C.; de Marsac, N.T.; Dittmann, E. Microcyclamide Biosynthesis in Two Strains of Microcystis aeruginosa: from Structure to Genes and Vice Versa. Appl. Environ. Microbiol. 2008, 74, 1791-1797.

134. Long, P.F.; Dunlap, W.C.; Battershill, C.N.; Jaspars, M. Shotgun Cloning and Heterologous Expression of the Patellamide Gene Cluster as a Strategy to Achieving Sustained Metabolite Production13. ChemBioChem 2005, 6, 1760-1765.

135. Jüttner, F.; Todorova, A.K.; Walch, N.; von Philipsborn, W. Nostocyclamide M: a cyanobacterial cyclic peptide with allelopathic activity from Nostoc 31. Phytochemistry 2001, 57, 613-619.

136. Banker, R.; Carmeli, S. Tenuecyclamides A-D, Cyclic Hexapeptides from the Cyanobacterium Nostoc spongiaeforme var. tenue. J. Nat. Prod. 1998, 61, 1248-1251.

137. Linington, R.G.; Gonzalez, J.; Urena, L.-D.; Romero, L.I.; Ortega-Barria, E.; Gerwick, W.H. Venturamides A and B: Antimalarial Constituents of the Panamanian Marine Cyanobacterium Oscillatoria sp. J. Nat. Prod. 2007, 70, 397-401.

138. Ogino, J.; Moore, R.E.; Patterson, G.M.L.; Smith, C.D. Dendroamides, New Cyclic Hexapeptides from a Blue-Green Alga. Multidrug-Resistance Reversing Activity of Dendroamide A. J. Nat. Prod. 1996, 59, 581-586.

139. Ishida, K.; Nakagawa, H.; Murakami, M. Microcyclamide, a Cytotoxic Cyclic Hexapeptide from the Cyanobacterium Microcystis aeruginosa. J. Nat. Prod. 2000, 63, 1315-1317.

140. Gatesoupe, F.J. Updating the importance of lactic acid bacteria in fish farming: natural occurrence and probiotic treatments. J. Mol. Microbiol. Biotechnol. 2008, 14, 107-114.

141. Wang, Y.-B.; Li, J.-R.; Lin, J. Probiotics in aquaculture: Challenges and outlook. Aquaculture 2008, 281, 1-4.

142. Hong, H.A.; Duc, L.H.; Cutting, S.M. The use of bacterial spore formers as probiotics. FEMS Microbiol. Rev. 2005, 29, 813-835.

143. Vine, N.G.; Leukes, W.D.; Kaiser, H. Probiotics in marine larviculture. FEMS Microbiol. Rev. 2006, 30, 404-427.

144. Das, S.; Ward, L.; Burke, C. Prospects of using marine actinobacteria as probiotics in aquaculture. Appl. Microbiol. Biotechnol. 2008, 81, 419-429.

145. von Wright, A. Regulating the Safety of Probiotics - The European Approach. Curr. Pharm. Des. 2005, 11, 17-23.

146. 101.70, C. Subpart E-Specific Requirements for Health Claims. Code Fed. Regul. 2005, 21, 126-129. 
147. Sahu, M.; Swarnakumar, N.; Sivakumar, K.; Thangaradjou, T.; Kannan, L. Probiotics in aquaculture: importance and future perspectives. Indian J. Microbiol. 2008, 48, 299-308.

148. Guo, J.-J.; Liu, K.-F.; Cheng, S.-H.; Chang, C.I.; Lay, J.-J.; Hsu, Y.-O.; Yang, J.-Y.; Chen, T.-I. Selection of probiotic bacteria for use in shrimp larviculture. Aquaculture Res. 2009, 40, 609-618.

149. Ruiz-Ponte, C.; Samain, J.F.; Sánchez, J.L.; Nicolas, J.L. The Benefit of a Roseobacter Species on the Survival of Scallop Larvae. Mar. Biotechnol. 1999, 1, 52-59.

Samples Availability: Available from the authors.

(C) 2010 by the authors; licensee Molecular Diversity Preservation International, Basel, Switzerland. This article is an open-access article distributed under the terms and conditions of the Creative Commons Attribution license (http://creativecommons.org/licenses/by/3.0/). 